\title{
PEMIKIRAN HUKUM HAZAIRIN
}

\author{
Wahidah \\ Fakultas Syariah dan Ekonomi Islam IAIN Antasari, Jl. Jenderal Ahmad Yani Km 4,5 Banjarmasin \\ E-mail: wahidah.antasari@gmail.com
}

\begin{abstract}
Hazairin is an intellectual of Islamic law. Although most of his live and education are in common education, not in speciality of islamic way, but Islam that was learned autodidactly makes he becoming a great man as modern islamic reformer. He concluded that social system in what Qur'an wants is not a clan system or anti-unilaterality. In one side, seriousness of thinking that was produced by Hazarin is considered as controversial statement. In the other side, his recent breakthrough has been realized through a number of Law rules.
\end{abstract}

\begin{abstract}
Abstrak: Hazairin adalah seorang pembela hukum Islam yang gigih. Meski hidup dan pendidikannya banyak dihabiskan dalam dunia pendidikan umum, namun Islam yang dipelajarinya secara autodidak justru telah mengharumkan namanya dengan julukan sebagai tokoh pembaharu hukum Islam modern. Dia menyimpulkan bahwa sistem kemasyarakatan yang dikehendaki al Qur'an adalah sistem yang bukan berklan-klan atau anti unilateral. Kesungguhan berpikir yang telah dihasilkan Hazairin, di satu sisi terkadang dianggap sebagai pendapat yang kontroversial, namun di sisi lain terobosan barunya ini justru telah diirealisasikan melalui sejumlah aturan perundang-undangan.
\end{abstract}

Kata kunci: Waris, bukum, Pemikiran, Undang-undang.

\section{Pendahuluan}

Nama Hazairin bukan lagi nama yang asing bagi masyarakat Indonesia, terutama bagi para peminat atau pemerhati hukum, baik hukum umum, maupun hukum Islam. Dia termasuk salah seorang pakar yang mempunyai keahlian luar biasa. Pada dirinya melekat dua keahlian, yaitu pakar hukum adat sekaligus pakar hukum Islam. Kedua keahlian ini berjalan seiring dan sama-sama menonjolnya. ${ }^{1}$

\footnotetext{
1 Mimbar Hukum, No. 44 Tahun X, 1999, SeptemberOktober, PT. Tomasu, hal. 65. Beberapa studi yang mengkaji pemikiran-pemikiran Hazairin antara lain, Panitia Penerbitan Buku, pembaharuan Hukum Islam di Indonesia: In Memoriam Prof. Dr. Haqairin, Jakarta, UI Press, cet.1, 1976; Abdul Gafir, Pemikiran Prof. Dr. Hazairin, SH. dalam Pembaharuan Hukum Kekeluargaan Islam, Skripsi Fakultas Syariah IAIN Sunan Kalijaga, Yogyakarta, 1987; Baidlowi, Konsepsi Hazairin tentang Hukum Kewarisan Islam, Skripsi Fakultas Syariah IAIN Sunan Kalijaga, Yohyakarta, 1988; Damrah Khair, Hukum Kewarisan Islam dalam Pandangan Hazairin, Tesis Program Pascasarjana IAIN Jakarta, 1988; Iskandar Ritonga, Pemikiran Hazairin tentang Pembaharuan Hukum Islam di Indonesia, Tesis Program Pascasarjana IAIN Jakarta, 1995; Al yasa Abu
}

Memang suatu hal yang perlu dikaji, kenapa sosok Hazairin yang dikenal sebagai orang yang menekuni pendidikannya di lembaga pendidikan umum, dan tidak pernah tercatat belajar secara formal pada lembaga pendidikan Islam. Mampu menjadi seorang pakar hukum Islam terkenal. Di pihak lain, nama Hazairin lebih populer di dunia perguruan tinggi (dunia ilmiah), ketimbang kiprahnya di pentas politik sebagai seorang politisi, padahal dia pernah menjabat sebagai Menteri Dalam Negeri pada kabinet Ali SastroamidjojoWongsonegoro (1953-Oktober 1954).

Umat Islam Indonesia patut berterimakasih atas segala upaya dan terobosan-terobosan yang dipersembahkan Hazairin sepanjang hidupnya

Bakar, Abli Waris Sepertalian Darah, Kajian Perbandingan Terhadap Penalaran Hazairin dan Penalaran Fiqh Madzhab; Disertasi, jakarta, terbitan INIS, cet.1, 1988; Muhammad Ja'far, Polemik Antara Prof. Dr. Hazairin dan Para Pengkeritiknya Mengenai Hukum Kewarisan Bilateral Menurut Alqur'an dan Hadith: Suatu Perbandingan, Disertasi, PPS IAIN Jakarta, 1993. 
kepada nusa, bangsa dan agama. Dia merupakan salah satu tokoh yang begitu gigih berada di garda terdepan menyuarakan dan membela keberadaan hukum Islam agar hukum Islam bisa dilaksanakn di bumi nusantara. Dia tampil bersuara keras, ketika Snouck Hurgronje lewat teorinya itu, melancarkan usaha-usaha untuk menggusur eksistensi hukum Islam dari Indonesia, dan secara perlahan-lahan menggerogoti wewenang Peradilan Agama. Dia menghujat teori tersebut dengan menyebutnya sebagai teori iblis karena teori yang menghalanghalangi berlakunya hukum Islam di Indonesia ini, mengajak orang Islam untuk tidak mematuhi dan melaksanakan perintah Allah dan sunnah RasulNya.

Tidak cukup hanya sampai di situ, dia juga ikut menggedor pintu ijtihad yang sudah lama ditutup oleh kaum muslimin Indonesia. Dia mengatakan bahwa pintu ijtihad tidak pernah tertutup, dan tidak ada orang yang berhak menutupnya. Dia tampil memformulasikan pikiranpikira segarnya yang disesuaikan dengan watak dan budaya masyarakat Indonesia, dan telah mengajukan berbagai konsepnya, mulai dari bidang perkawinan, kewarisan, pidana, politik, hingga demokrasi Pancasila. Kesemua hasil pikiran yang diwariskannya itu, telah ikut memperkaya khazanah keilmuan di Indonesia.

Seperti halnya Hasbi Ash Shiddieqy (19041975), pakar hukum Islam lainnya yang hidup semasa dengannya, hazairin juga menyuarakan perlunya dibentuk madzhab nasional bagi umat Islam Indonesia. Madzhab ini kemudian, setelah mengalami beberapa pertimbangan, beliau ganti namanya menjadi Madz̧hab Indonesia. ${ }^{2}$ Dalam upaya mewujudkan idenya ini, ia telah berijtihad untuk mengeluarkan pendapat-pendapatnya dengan tetap konsekuen berpegang pada sumber asli Alqur'an dan hadits yang menjadi rujukannya.

Singkatnya, kiprah Hazairin di dunia perguruan tinggi, di tengah-tengah kehidupan umat Islam, serta di dunia politik itulah yang telah menghantarkan namanya pada posisi yang penting. Oleh karena itu, sudah sepantasnya bila perjalanan hidup serta percikan-percikan pemikirannya

2 Tentang perubahan ini, lihat Hukum Kekeluargaan Nasional, Tintamas, Jakarta, 1982, cet.III. hal.5-6. Menurutnya, jika memakai nama madzhab nasional, maka mencakup segenap warga negara, padahal masyarakat Islam Indonesia hanyalah sebgaian saja dari bangsa Indonesia. kembali diangkat, agar bisa dipetik hikmah dan pelajaran darinya.

\section{Biografi Hazairin}

Hazairin adalah seorang ahli hukum Islam sekaligus hukum adat Indonesia pertama dari kalangan putra Indonesia. Ia termasuk salah seorang nasionalis dan intelektual muslim Indonesia yang berpendidikan Barat (Belanda ). Nama lengkapnya adalah Hazairin Gelar Pangeran Alamsyah Harahap. ${ }^{3}$

Beliau dilahirkan di Bukit Tinggi, 28 Nopember 1906, putra Zakaria Bahri, seorang guru sekaolah rakyat, kakeknya bernama Ahmad Bakar, seorang ulama dan muballig asal Bengkulu. Pendidikan agama sudah diperoleh hazairin sejak kecil di lingkungan keluarga. Pendidikan Agama inilah yang membentuk sikap keagamaannya yang demikian kuat dalam perjalanan karir dan hidupnya serta mewarnai pemikirannya meskipun secara formal ia banyak menuntut ilmu di lembaga pendidikan Hindia Belanda.

Hazairin menjalani pendidikan formal pertama di HIS (Hollands Inlandsche School) di Bengkulu dan tamat pada tahun 1920; lalu melanjutkan di MULO (Meer Uitgebreid Lagere Onderwijs) di Padang dan tamat pada tahun 1924; kemudian meneruskannya lagi ke AMS (Algemene Middlebare Schooal) di Bandung dan tamat 1927. Ia melanjutkan pendidikannya di Rechtskundige Hodeschool (Sekola Tinggi Hukum) di batavia dan lulus serta meraih gelar doktor di bidang hukum adat pada 29 Mei 1936 setelah mempertahankan disertasinya dengan judul De Redjang. ${ }^{4}$

Sejak 1935 sampai 1938 Hazairin menjadi asisten dosen pada almamaternya dalam mata kuliah hukum adat dan antropologi. Tiga tahun setelah lulus ujian sampai datangnya Jepang, Hazairin ditugaskan pemerintah Hindia Belanda di Pengadilan Negeri padang Sidempuan dengan tugas tambahan sebagai peneliti hukum adat Tapanuli Selatan. Karena pengetahuannya yang luas tentang hukum adat setempat, masyarakat Tapanuli Selatan memberinya gelar "Pangeran Alamsyah Harahap".

\footnotetext{
3 Ensiklopedi Islam 3, PT. Ichtiar Baru Van Hoeve, hlm. 13.

4 Ibid. Redjang adalah salah satu suku yang terdapat di Keresidenan Bengkulu.
} 
Pada masa pendudukan Jepang, ${ }^{5}$ yaitu tahun 1945, Hazairin pernah menjadi anggota Gerakan Pemuda Bawah Tanah, suatu organisasi rahasia di kalangan pemuda pergerakan yang bertujuan mengusir penjajah dari tanah air. Anggotanya terdiri dari para pemuda, baik yang tergabung dalam peta ataupun bukan.

Pada masa perang kemerdekaan antara 1945 1949 Hazairin bergabung dengan tentara pelajar. Pada tahun 1946 ia menjadi komandan Brigade Tentara Pelajar di Kalimantan. Pada tahun itu juga ia menjadi bupati Sibolga. Tahun 1946-1950, ia diangkat pemerintah Republik Indonesia menjadi residen Bengkulu sekaligus menjadi wakil gubernur militer Sumatera Selatan sampai 1953. Tahun itu Hazairin diangkat menjadi pegawai tinggi yang bertugas sebagai kepala bagian hukum perdata Kementerian Kehakiman. Setahun kemudian, dari Agustus 1953 sampai Oktober 1954, ia diangkat menjadi Menteri dalam Negeri dalam kabinet Ali Sastroamodjojo-Wongsosuseno-Muhammad Roem.

Sebagai aktivis politik, tahun 1948 ia ikut mendirikan Partai Persatuan Indonesia Raya, pecahan dari Partai Nasional Indonesia (PNI), yang kemudian diketuai Wongsonegoro dan Hazairin duduk sebagai wakil ketua I. Di Dewan Perwakilan Rakyat Sementara sebelum diadakan pemilu pertama, PIR mempunyai tiga orang wakil, yaitu Wongsonegoro, Rooeseno, dan Hazairin sendiri. Dalam kedudukannya sebagai salah seorang pemimpin PIR itulia duduk dalam kabinet AliWongso-Roemah sebagai Menteri Dalam Negeri, dengan tugas utama mempersiapkan pemilu pertama.

Sampai 1959 Hazairin berstatus sebagai pegawai tinggi Kementerian Kehakiman. Pada tahun yang sama ia dipindahkan ke Kementerian Pendidikan dan Pengajaran dan Kebudayaan sebagai guru besar hukum adat di fakultas Hukum Universitas Indonesia. Di samping itu ia juga

\footnotetext{
5 Ia diangkat sebagai penasehat hukum. Tugas ini dipangkunya sampai Indonesia merdeka (1942-1945). Setelah kemerdekaan, Hazairin melanjutkan tugasnya di Tapanuli Selatan. Selang waktu enam bulan (Oktober 1945-April 1946), ia menjabat Ketua Pengadilan Negeri daerah itu, merangkap Ketua Komite Nasional Indonesia (KNI) dan Anggota Pusat Pemerintah Tapanuli, Asisten Residen, dan Kepala Luhak. (Lihat Tim Redaksi Majalah Tempo, Apa dan Siapa Sejumlah Orang Indonesia 1981-1982), Grafiti Pers, Jakarta, 1981, hlm. 219.
}

mengajar di Akademi Hukum Militer, Pendidikan Tinggi Ilmu Kepolisian (PTIK), dan Universitas Islam Jakarta.

Pada tahun 1950 hazairin bersama temantemannya mendirikan Yayasan Wakaf Perguruan Tinggi Islam. Dari yayasan inilah lahir Universitas Islam Jakarta. Sebagai pendiri dan ketua yayasan tersebut, tahun itu juga ia diangkat sebagai rektor pertamanya sampai tahun 1960. Sejak itu sampai akhir hayatnya, Hazairin tercatat sebagai anggota dewan kurator Institut Agama Islam Negeri Syarif Hidayatullah Jakarta.

Pemikirannya tertuang dalam publikasi ilmiah di berbagai media massa, jurnal dan buku yang ditulis dalam bahasa Indonesia, Belanda dan perancis. Karya monumentalnya tidak kurang dari 17 buku, antara lain de Redjang dalam bahasa Belanda, ditulis tahun 1936; De Gevolgen van de Huwelijksontbinding in Zuid Tapanuli (Akibat Perceraian Perkawinan di Tapanuli Selatan), hasil penelitiannya selama bertugas menjadi penyelidik hukum adat Tapanuli, 1941; Reorganisatie van het Rechtwesen in Zuid Tapanuli (Reorganisasi Hukum di Tapanuli Selatan); Le Droit Sur Le Sol en Indonesia (Hukum tentang pertanahan di Indonesia), Belgia 1952; Indonesia Satu Masjid, Jakarta 1952; Pergolakan Penyesuaian Adat kepada Hukum Islam, Jakarta 1952; Hukum Islam dan Masyarakat, Jakarta, tanpa tahun; Hukum Kewarisan Bilateral Menurut Al-Qur'an, Jakarta, 1958; Hendak Kemana Hukum Islam, Jakarta,1960; Hadis Kewarisan Bilateral, Jakarta, 1962; Hukum Kekeluargaan Nasional, Jakarta, 1962; Isa Al-Masih dan Roh, Jakarta, 1969; Demokrasi Pancasila, Jakarta, 1970 dan Tujuh Serangkai tentang hukum, Jakarta, 1973. ${ }^{6}$

Meskipun mendapat pendidikan ilmu hukum di lembaga pendidikan barat yang sekuler, Hazairin ${ }^{7}$ juga secara autodidak mempelajari hukum Islam atau pendidikan agama dan bahasa Arab dari ayahnya, terutama sekali dari kakeknya. Untuk memahami lebih lanjut ajaran Islam ia belajar sendiri. Ia menguasai bahasa Belanda, Inggris, dan Perancis secara aktif, dan bahasa Arab, Jerman dan latin secara pasif. Pemikirannya, khususnya dalam

\footnotetext{
Ensiklopedi Islam 3, op cit, hlm. 14.

Suami Aminah, dan bapak dari 13 orang anak (Asmara Dewi, Nurlela Cindarwati, AbdulHakim, saladin, Chaerati, Chaerani, Zulkarnain, Hermaini, Zulkifli, Zulfikar, Puspa Juwita, zainul Harmain, dan Soraya Farida.
} 
bidang hukum, selalu dikembalikan kepada sumber agama yang dianutnya, yaitu Alqur'an dan hadits. Yang demikian itu muncul bukan saja karena ia seorang muslim yang taat, tetapi juga atas dasar kenyataan bahwa mayoritas rakyat Indonesia menganut agama Islam.

Demikianlah setelah 69 tahun beliau mempersembahkan pengabdiannya kepada nusa, bangsa dan agama, pada tanggal 12 Desember 1975 diapun kembali ke hadhirat Allah swt., seminggu setelah meninggalnya Tengku M. Hasbi Ash Shiddieqy. Hazairin wafat dan dikebumikan dalam suatu upacara kenegaraan di Taman Makam Pahlawan Kalibata, Jakarta. Atas jasanya, pemerintah Republik Indonesia menganugerahinya Satya Lencana Widya Satia, Bintang Gerilya dan Bintang Bhayangkara Kelas III serta Bintang Kartika Eka Paksi Kelas III. Namanya kemudian diabadikan pada sebuah jalan dan universitas yang keduanya berada di Bengkulu.

\section{Ide-Ide Pemikiran Hazairin}

Di tengah-tengah pemikir muslim Indonesia abad ke 20, ia merupakan salah seorang tokoh yang gigih menyuarakan dan memperjuangkan pelaksanaan hukum Islam di Indonesia. Ia mengatakan bahwa bangsa Indonesia akan bahagia jika hukum yang berlaku di Indonesia adalah syariat agama atau sekurang-kurangnya hukum yang tidak bertentangan dengannya. Terkait itu, ia menyerang keras terhadap teori Receptie yang dikembangkan ahli hukum Belanda, Christian Snouck Hurgronje dan Lodewijk William Van den Berg sampai gurunya sendiri Van Vollen Hoven.d

Teori ini adalah kebalikan dari teori Receptio in Complexu. Bermula dari penelitian Hurgronje yang menyatakan bahwa di dua daerah masyarakat beragama Islam, Aceh dan Gayo, yang berlaku bukanlah hukum Islam. ${ }^{8}$ Hukum Islam yang berlaku di Indonesia hanyalah hukum Islam yang sudah diterima sebagai hukum adat. Teori ini cukup banyak berpengaruh di kalangan sarjana hukum Indonesia, ${ }^{9}$ dan Hazairin mengingatkan mereka

8 A. Qodri Azizy, Eklektisisme Hukum Nasional Kompetisi antara Hukum Islam dan Hukum Umum, Gama Media, Yogyakarta, Pebruari 2002, cet. pertama, hal. 155.

9 Menurut penganutnya, orang Islam Jawa dan Madura hanya tunduk pada hukum kewarisan Islam, jika mereka membagi warisan itu di depan Pengadilan Agama, kalau di luar Pengadilan tersebut, maka mereka akan membaginya berdasarkan hukum adat. Kenyataan ini dengan mengatakan bahwa teori ini merupakan teori iblis, teori yang memusuhi berlakunya hukum Tuhan di bumi Indonesia. Bagi Hazairin, hukum Islam harus diberlakukan bagi orang Islam, baik sudah menjadi hukum adat atau belum.

Hazairin menganjurkan umat Islam Indonesia agar berijtihad, menggali hukum Islam secara langsung dari sumbernya, menuju pembentukan madzhab baru yang sesuai dengan kondisi sosiokultural khas masyarakat Indonesia, dan tidak bertaklid pada suatu pendapat atau madzhab. Ia megkritik sikap taqlid ulama yang menurutnya menjadi penyebab utama kebekuan pemikiran fiqih, selain disebabkan oleh hukum fiqih yang diproduksi para teoritisi hukum di belakang meja. Sebagai akibatnya hukum fiqih membeku selama ribuan tahun, sementara ulama beranggapan bahwa kitabkitab fiqih itu begitu suci dan keramat, yang resisten terhadap perubahan, sehingga mampu menggantikan kedudukan Alqur'an.

Ia mengatakan bahwa manusia tanpa sengaja menambah rukun iman, dengan beriman kepada ulama-ulama masa lalu, padahal pemikiran mereka tidak terjamin kekal dan aktual sepanjang zaman. Oleh karena itu, perlu diadakan kajian ulang terhadap fiqih yang ada dengan kebebasan ijtihad dan menghilangkan taqlid, guna mempertautkan hukum adat dengan kehendak Ilahy. Menurutnya hukum Qur'an dapat dijalankan di segala penjuru dunia Islam dengan syarat umat Islam tidak menjadikan tiap-tiap penjuru itu persis seperti masyarakat Arab, selain bangkit menggiatkan upaya-upaya ijtihad yang langsung diambil dari sumber asli.

Di abad ini, orang tidak perlu lagi mendewadewakan mujtahid, sebab ijtihad mereka dinilai (hanya) cocok untuk zamannya, dan belum tentu

menjadi bukti bahwa hukum kewarisan Islam tidak memenuhi rasa keadilan masyarakat Indonesia, dan dalam beberapa hal hukum Islam sama sekali ditolak oleh hukum adat, sebagaimana halnya di Minangkabau, Jawa dan madura. Untuk memperkuat argumentasinya, mereka mengemukakan contoh anak-anak angkat yang tidak dapat menerima bagian dari warisan Islam, meskipun soal pengangkatan anak serta hak memperoleh warisan berlaku sangat luas di kalangan masyarakat Jawa. Lihat Daniel S. Lev, Peradilan Agama Islam di Indonesia: Suatu Studi tentang Landasan Politik Lembaga-Lembaga Hukum, terj. Z.A. Noeh dari Islamic Courts in Indonesia, PT. Intermasa, Jakarta, 1980, cet. I, hal. 104, sebagaimana dikutip dalam Mimbar Hukum, hlm. 81-82. 
sesuai dengan kebutuhan bangsa Timur sekarang. Apa yang sesuai hari ini, boleh jadi tidak untuk hari esok. Kitab-kitab fiqih yang ditulis liam atau enam abad yang lalu, selain sudah tua juga mengandung ekspresi Timur tengah. Artinya ia lebih bersifat partikulastik, lokal dan tidak universal.

Sehubungan dengan itu, ia berharap agar dari institusi-institusi pendidikan yang ada akan lahir mujtahid-mujtahid, yang tidak hanya memenuhi persyaratan sebagai seorang mujtahid, tapi juga menguasai ilmu-ilmu kemasyarakatan, semisal imu hukum modern dan antropologi. Dalam diri mujtahid hendaknya terdapat kemampuan seorang ahli hukum (jurist) modern, sekaligus kesanggupan ulama modern. ${ }^{10}$ Sebab menurutnya, jurist modern saja tidak sanggup menjalankan tugasnya dalam masyarakat Islam, meski telah diberi pelajaran hukum Islam, karena hukum Islam yang diperolehnya hanya sedikit sekali, sedangkan ilmu alatnya, agar dapat menggali sendiri ilmu-ilmu keislaman tidak diperoleh pada institusi pendidikan hukum biasa. Di sisi lain, ulama saja, meskipun ulama modern, tapi tidak mengetahui ilmu hukum modern, tidak pula sanggup melayani kebutuhan masyarakat Islam.

Prototipe yang diinginkan Hazairin inilah yang selalu diperlukan di era modern sekarang ini. Sebab yang dibutuhkan adalah ahli-ahli yang bisa membahasakan hukum-hukum Islam baik yang terdapat dalam Alqur'an dan hadits, maupun yang terdapat dalam kitab-kitab fiqih, ke dalam bahasa perundang-undangan modern, yang aktual, rasional serta sistematis. ${ }^{11}$

Mengenai bentuk Madrhab Indonesia yang diinginkannya, ia menyatakan bahwa madzhab Indonesia itu adalah madzhab Syafi'i yang diperbaharui. Beberapa masalah yang perlu diperbaharui dalam ketentuan-ketentuan ini antara lain menyangkut masalah zakat dan baitul mal yang harus disesuaikan dengan tuntutan modern dalam alam negara pancasila. Masalah perkawinan, yang memerlukan beberapa revisi, selaras dengan perkembangan zaman. Kemudian perlunya dilakukan emansipasi wanita Indonesia, serta pembentukan masyarakat yang bercorak parental, termasuk persoalan kewarisannya. ${ }^{12}$

\footnotetext{
${ }^{10}$ Hazairin, Hukum Baru di Indonesia, hal. 154-155, sebagaimana dikutip dari Mimbar Hukum, hlm. 71.

11 Ibid.

${ }^{12}$ Lebih lanjut, dapat diikuti dalam bahasan tentang ideide pemikirannya terkait dengan masalah kewarisan yang
}

Terkait dengan teori Receptie yang ditentangnya secara keras, dan terbukti tidak benar, Hazairin, selain untuk tetap mempertahankan kewenangan Pengagilan Agama di bidang kewarisan, ia juga mengusulkan perlunya penyeragaman Pengadilan Agama di seluruh Indonesia, tanpa harus membedakan Jawa dan luar Jawa, baik dalam hal nama, maupun materi hukumnya, yang berwenang menangani masalah bukan hanya persoalan perkawinan, tetapi juga bidang kewarisan. Termasuk usulannya agar tercipta Pengadilan Agama yang mandiri, tanpa harus mendapat pengukuhan dari Pengadilan Negeri sebelumnya. Tidak hanya itu, ia juga menyerukan agar di seluruh Indonesia memiliki undang-undang atau peraturan pemerintah di bidang hukum keluarga Islam. ${ }^{13}$

Satu di antara persoalan yang termasuk dalam bidang hukum keluarga Islam, masalah perkawinan tampaknya juga menjadi bagian telaah penting dari hazairin. Pakar hukum adat ini secara langsung telah melakukan penelitiannya terkait dengan praktik larangan perkawinan adat yang menurutnya masih perlu diluruskan sesuai konsep hukum yang terkandung dalam ayat-ayat Alqur'an, dihubungkan dengan sistem kemasyarakatan yang "diridhoi".

Hukum menentukan bentuk masyarakat. Masyarakat yang belum dikenal dapat dicoba mengenalnya pada pokok-pokoknya dengan mempelajari hukum yang berlaku dalam masyarakat itu; hukum mencerminkan masyarakat. Dari seluruh hukum maka hukum perkawinan dan kewarisan yang menentukan dan mencerminkan sistem kekeluargaan yang berlaku dalam masyarakat yang pada pokoknya terdapat tiga macam sistem keturunan yaitu, patrilineal, matrilineal, dan parental atau bilateral.

Kekeluargaan ditimbulkan pada prinsipnya karena perkawinan. Benteng untuk mempertahankan bentuk masyarakat yang bercorak patrilineal ataupun matrilineal ialah perkawinan yang exogami, dimana terlarang perkawinan antara laki-laki dan perempuan yang se clan. Dalam masyarakat yang matrilineal seseorang laki-laki dan perempuan

oleh sebagian pihak dinilai sebagai pendapat yang kontroversial.

${ }^{13}$ Hazairin, Tujuh Serangkeai tentang Hukum, Bina Aksara, 1981, cet. II, hlm. 39-40, dan 66.

${ }^{14}$ Hazairin, Hukum Kewarisan Bilateral Menurut Qur'an dan Hadits, Tintamas, Jakarta, 1982, cet. VI, hal.12. 
dilarang kawin, jika ibu dari laki-laki dan ibu dari perempuan tersebut se mak (mempunyai mak yang sama), demikian juga pelarangan dalam masyarakat yang patrilineal dengan adanya kesamaan bapak dari laki-laki dan perempuan tersebut, karena mereka dipandang satu clan. ${ }^{14}$

Qur'an dalam surah IV ayat 22, 23, 24, setelah merinci larangan-larangan perkawinan, memproklamirkan dalam ayat 24 nya dengan kehalalan, yakni tidak boleh dilarang dan tidak boleh dicela, semua macam perkawinan yang tidak termasuk dalam rincian pelarangan itu. Sehingga jelas tidak termasuk di dalamnya mengenai perkawinan sepupu, bentuk cross-cousins dan parallel-cousins.

Dengan terhapusnya berbagai larangan mengenai kawin sepupu itu, maka ikut terhapus pula larangan perkawinan se clan dalam masyarakat yang bercorak kebapakan dan keibuan ini, sekaligus menanggalkan syarat exogami dan menumbangkan clan yang berbentengkan exogami itu, dan secara otomatis akan menimbulkan masyarakat yang $b i$ lateral.

Jika Qur'an dipelajari dengan beralatkan ilmu tentang pelbagai bentuk kemasyarakatan, yakni tentang pelbagai jenis sistem kekeluargaan, sistem garis keturunan, maka ayat-ayat Qur'an di lapangan perkawinan dan kewarisan mencerminkan suatu bentuk sistem kekeluargaan yang bilateral. ${ }^{15}$

Masalah lain yang Hazairin coba merumuskannya dalam rangka mewujudkan madz̧ hab Indonesia adalah, mengenai persoalan kewarisan yang menurutnya bercorak bilateral. Ada tiga hal penting terkait dengan masalah kewarisan versinya ini, yaitu tentang sistem kewarisan bilateral, kedudukan mawali dan masalah kalalah. Satu persatu dapat dijelaskan sebagai berikut:

\section{Kewarisan Bilateral}

Hazairin menyatakan bahwa sistem kemasyarakatan yang terkandung dalam Alqur'an adalah sistem kemasyarakatan bilateral, dan karenanya sistem kewarisannyapun bercorak bilateral juga. Ia merujuk dan meyimpulkan ini, dengan mendasarkan pada surah al Nisa ayat 23 dan 24. Teorinya ini berbeda dengan pendapat ulama yang terdapat dalam kitab-kitab fiqih klasik yang telah dikenal luas oleh masyarakat Islam Indonesia, yang merumuskannya dengan sistem kewarisan bercorak patrilineal. Menurutnya,

15 Ibid, hlm. 13.
Alqur'an anti terhadap masyarakat yang unilateral (ber clan-clan) seperti patrilineal atau matrilineal. ${ }^{16}$

Berdasarkan hasil penelitiannya terhadap hukum adat yang berlaku di beberapa daerah Indonesia, ia menyatakan bahwa hukum kewarisan sunni yang bercorak patrilineal itu, bukannya tidak bermasalah (ada konflik) dengan hukum patrilineal yang ada di Indonesia, dan konflik-konflik itu sendiri bukan disebabkan oleh kitab suci Alqur'an, tapi oleh ikhtilaf manusia belaka. ${ }^{17}$

Terkait dengan ini, Qur'an dalam ayat-ayat kewarisannya secara langsung menunjuk sistem kekeluargaan dimaksud melalui surah IV:11 yang menjadikan semua anak, baik laki-laki ataupun perempuan, menjadi ahli waris bagi kedua orang tuanya (ayah ibunya). Berbeda dengan dua corak di atas yang pada prinsipnya hanya menjadikan anak laki-laki (dalam sistem patrilineal) sebagai ahli waris yang berhak, atau sebaliknya dalam sistem matrilineal yang anak-anaknya hanya bisa mewaris dari ibunya saja, tidak terhadap bapanya. ${ }^{18}$

Demikian pula ayat tersebut menjadikan ayah dan ibu menjadi ahli waris bagi anaknya yang mati punah. Ini adalah sistem bilateral, karena dalam dua sistem terdahulu, peningalan anak itu hanya diwarisi oleh bapaknya saja atau ibunya saja sesuai corak atau clan kebapakan dan keibuan.

Dalam surah yang sama ayat 176 , menjadikan saudara sebagai ahli waris terhadap saudaranya yang meninggal, tidak peduli apakah si mati itu laki-laki atau perempuan, demikian pula tidak peduli apakah saudara yang mewarisi itu laki-laki atau perempuan. Kenyataan seperti ini tidak berlaku bagi dua sistem kekeluargaan yang hanya memberikan pada saudara laki-laki saja untuk corak patrilineal atau terhadap saudara perempuan dalam masyarakat matrilineal. ${ }^{19}$

Dengan sendirinya, Qur'an pada hakikatnya hendak menghancurkan sistem masyarakat yang ber clan-clan dimaksud, untuk selanjutnya membangun masyarakat bilateral yang merupakan modelnya.

${ }^{16}$ Ibid, hal.1. Ijtihad ini ia yakini sejak tahun 1950, dan disampaikan dalam kesempatan kuliah-kuliahnya, seperti saat perayaan ulang tahun VI Perguruan Tinggi Islam Jakarta tanggal 17 Nopember 1957 dengan bahasan "Hendak Kemana Hukum Islam".

${ }^{17}$ Pernyataan ini disampaikan dalam bagian pendahuluan bukunya, hasil rangkuman dari karya Hukum Kewarisan Bilateral Menurut Alqur'an dan Hadith, dengan karyanya Kewarisan dan Sistem Bilateral.

18 Ibid, hlm. 14.

${ }^{19}$ Ibid. 
Hubungannya dengan sistem kemasyarakatan dan corak kewarisan Islam.Kewarisan di Indonesia mengenal tiga sistem kewarisan, yaitu individual, kolektif dan mayorat. ${ }^{20}$ Ketiga sistem kewarisan tidak langsung menunjuk kepada bentuk masyarakat dimana hukum kewarisan itu berlaku.

Berdasarkan hasil pemeriksaan yang telah dilakukan Hazairin dalam konteks ini, sistem kewarisan individual, tampaknya telah memenuhi unsur-unsur itu, sebab al Qur'an surah al Nisa ayat 7 dan 33, mengandung prinsip-prinsip dimaksud. Ahli waris masing-masing berhak atas suatu bagian yang pasti, dan bagian-bagian ituwajib diberikan kepada mereka. Ayat 8 secara sengaja menyebut al qismah, yaitu pembagian, sedangkan di ayat 11, 12, dan 176 merupakan ketentuan selanjutnya menyangkut bagian untuk para warisnya. ${ }^{21}$

Hubungannya dengan masalah garis pokok keutamaan dan penggantian sebagaimana yang dimaksudkan dalam sistem kewarisan individual dalam masyarakat yang bilateral di Indonesia, ia membagi ahli waris itu dalam tiga jenis, yaitu dzawul faraidh, drawul qarabat dan mawali.

\section{Kedudukan Mawali}

Ijtihad Hazairin tentang masalah waris pengganti, muncul karena ia merasakan adanya ketidakadilan dalam pembagian warisan yang ada selama ini, yakni bahwa cucu perempuan yang ayahnya meninggal lebih dahulu darti pewaris tidak mendapat bagian (harta warisan) yang ditinggalkan kakeknya. Olehnya, kata mawali sebagaimana dalam

\footnotetext{
${ }^{20}$ Masing-masing sistem mempunyai ciri sebagai kekhasannya. Bagi sistem kewarisan individual, harta peninggalan dapat dibagi-bagikan pemilikannya di antara ahli waris, seperti dalam masyarakat bilateral di Jawa dan masyarakat patrilineal di Tanah Batak. Sistem kolektif, harta peninggalannya, diwarisi oleh sekumpulan waris merupakan semacam badan hukum, dan hartanya yang disebut dengan hartapusaka itu tidak boleh dibagi-bagikan pemilikannya terhadap ahli warisnya, dan hanya boleh dibagi-bagikan pemilikannya kepada mereka itu, seperti dalam masyarakat matrilineal Minangkabau. Sedangkan sistem yang mayorat, menghendaki anak tertua pada saat matinya pewaris, sebagai orang yang berhak tunggal untuk mewarisi seluruh harta peninggalan, atau berhak tunggal untuk mewarisi sejumlah harta pokok dari satu keluarga, seperti dalam masyarakat patrilineal yang beralihalih di Bali (hak mayorat anak laki-laki tertua) dan di Tanah Semendo Sumatera Selatan (hak mayorat anak perempuan yang tertua).

${ }^{21}$ Ibid, hlm. 17.
}

ayat 33 surah al Nisa, dipahami sebagai waris pengganti atau plaatsvervulling dalam Budgerlijk Weetboek. Atau mawali yang dimaksudkan adalah orang-orang yang menjadi ahli waris karena tidak ada lagi penghubung antara mereka dengan pewaris, dan menurutnya ia juga termasuk dalam pengertian aqrabun. $^{22}$

Pengertian ini bertolak dari paham yang dianut, bahwa surah al Nisa ayat 33 itu dapat diterjemahkan sebagai berikut: "Bagi mendiang anak, Allah mengadakan mawali sebagai ahli waris dalam harta peninggalan ayah atau mak; dan bagi mendiang aqrabun, Allah mengadakan mawali sebagai ahli waris dalam harta peninggalan sesama aqrabunnya".

Jika kalimat panjang ini dipendekkan maka ia boleh berbunyi: "Bagi mendiang anak dan bagi mendiang keluarga dekat, Allah mengadakan mawali bagi harta peninggalan orang tua dan kerabat dekat". Kalimat ini pendek tetapi kurang jelas dan dapat mengacaukan. Jika dibikin lebih pendek lagi dengan kalimat "Bagi setiap orang, Allah mengadakan mawali bagi harta peninggalan orang tua dan keluarga dekat", maka tidak akan mengacaukan jika orang langsung berpikir menurut hubungan bertimbalan dalam setiap istilah kekeluargaan.

Jika pewaris orang tua, maka hubungannya bertimbalan yang langsung bagi istilah itu adalah anak, dan jika si pewaris keluarga dekat, maka hubungan bertimbalan yang langsung bagi istilah itu ialah keluarga dekat. Umpama saudara sebagai pewaris timbalannya saudara pula, bukan anak itu atau saudara itu yang menjadi ahli waris, tetapi mawalinya, sehingga anak atau saudara itu mesti telah mati terlebih dahulu dari pewaris, sebab jika anak atau saudara itu masih hidup, maka ia berdiri sendiri sebagai ahli waris, dan Allah tidak mengadakan lagi ahli waris yang lain.

Atas dasar ini, Hazairin berpendapat bahwa maksud mengadakan mawali untuk si fulan itu ialah bahwa bagian si fulan, yang akan diperolehnya, seandainya dia hidup, dari harta peninggalan itu, dibagi-bagikan kepada mawalinya itu, bukan sebagai

22 Ibid, hlm 32. Berarti ulul qurba seseorang yang ada pertalian nasab dengan pewaris tetapi masih memiliki penghubungnya yang masih hidup dengan muwarrits, maka dia tidak berhak mewaris. Inilah garis pokok penggantian menurut al Qur'an yang dipahami memalui ayat dimaksud. 
ahli warisnya tetapi sebagai ahli waris ahli waris bagi ibunya atau ayahnya yang meninggalkan harta itu. Yang digambarkan itu mungkin keadaan seorang ayah atau ibu yang diwarisi oleh anak-anaknya bersama-sama dengan mawali bagi anak-anaknya yang telah mati lebih dahulu. Pengertian selanjutnya ialah mungkin pula jika ayah atau ibu itu diwarisi hanya oleh mawali untuk anak-anaknya yang semuanya telah mati terlebih dahulu.

Contoh terhadap ayah atau ibu sebagai pewaris, dapat diperluas dengan lain-lain pewaris dari kalangan aqrabun, umpamanya saudara diwarisi oleh saudara bersama-sama dengan mawali bagi saudara-saudara yang telah mati terlebih dahulu, atau hanya oleh mawali bagi saudara-saudara saja, demikian pula dapat diperluas dengan seseorang yang mati punah dengan tidak ada pula saudara atau keturunan saudara sebagai ahli waris, maka dia diwarisi oleh mawali bagi orang tuanya jika orang tuanya itu telah mati pula lebih dahulu.

Terkait itu, Hazairin berdasar atas pemahamannya terhadap ayat-ayat kewarisan, ia merekonstruksi apa yang disebutnya dengan istilah prinsip keutamaan yang ada dalam al Qur'an itu dengan rumusan seperti berikut (setelah melakukan perubahan dan penyesuaian) :

1. Keutamaan pertama, anak laki-laki dan perempuan atau sebagai dzawul faraidh (dzawul qarabat) berserta mawali bagi mendiangmendiang anak-anak tersebut, orang tua (ayah dan ibu) sebagai dzawul faraidh dan janda atau duda sebagai drawul faraidh.

2. Keutamaan kedua, saudara laki-laki dan perempuan sebagai drawul faraidh atau sebagai dzawul qarabat, beserta mawali bagi mendiang-mendiang saudara laki-laki dan perempuan dalam hal kalalah, ibu sebagai dzawul faraidh dan ayah sebagai dzawul qarabat dalam hal kalalah, serta janda atau duda sebagai drawul faraidh.

3. Keutamaan ketiga, ibu sebagai drawul faraidh, ayah sebagai dzawul qarabat dan janda atau duda sebagai dzawul faraidh.

4. Keutamaan keempat, janda atau duda sebagai drawul faraidh, mawali untuk ibu dan mawali untuk ayah. ${ }^{23}$

Oleh Hazairin, waris karena penggantian atau disebutnya dengan istilah mawali ini akan menerima

${ }^{23}$ Lihat hlm. 37-38 sumber yang sama. bagian sebanyak yang diterima orang oleh orang tuanya (ayah atau ibu) seandainya mereka masih hidup. Kedudukannya sama dalam satu jurai, akan berbagi di antara mereka menurut prinsip "laki-laki mendapat dua kali lipat dari perempuan". Pengganti ini merupakan prinsip yang bersifat umum dan terbuka sampai keturunan yang terbawah, dan bijab mabjub hanya diberlakukan dalam satu jurai. Yang digantikan maupun yang menggantikan tidak dibedakan antara laki-laki dan perempuannya. ${ }^{24}$

Ringkasnya, semua mawali berbagi antara mereka jumlah bagian orang untuk siapa mereka menjadi mawali dengan mengindahkan kedudukan mereka masing-masing dalam jurai dan selanjutnya atas dasar kesamaan kedudukan maka laki-laki dan perempuan berbagi dalam bandingan 2:1, samasama perempuan atau sama-sama laki-laki berbagi sama rata dan jika mawali itu tunggal, maka ia mendapat seluruhnya.

Sebagai illustrasi contoh, Hazairin mengemukakan penyelesaian kasus kewarisan mawali ini dengan membuat bandingannya versi sistem kewarisan individuil bilateral, sistem individuil patrilineal murni dan sistem matrilineal..$^{25}$ Dengan contoh-contoh itu ia menyatakan bahwa garis pokok penggantian itu tidak ada sangkut pautnya dengan ganti mengganti. Dia hanya cara untuk menunjukkan siapa saja ahli warisnya. Tiap-tiap waris itu berdiri sendiri sebagai ahli waris, bukan menggantikan ahli waris yang lain, sebab penghubung yang tidak ada lagi itu bukan ahli waris, sehingga soal representasi ataupun substitusi tidak ada. Selanjutnya, sebagai konsekuensi ajarannya yang menganut sistem kewarisan individuil bilateral, Hazairin pun membuat bandingan penyelesaian.

Gagasannya ini dimaksudkan sebagai upaya mengisi kekosongan yang terdapat dalam sistem hukum kewarisan Islam yang telah dianggap mapan. Padahal persoalan ini masih memerlukan penafsiran ulang, karena tidak diatur secara tegas (qath'i) di dalam al Qur'an. Akan tetapi ide yang dikemukakannya ini kurang mendapatkan sambutan dari ulama Indonesia, kecuali dalam kalangan terbatas, meskipun mereka menyadari bahwa dalam kasus tersebut gagasan Hazairin ini (sebenarnya) lebih dirasakan adil.

${ }^{24}$ Amrullah Ahmad, Dimensi Hukum Islam dalam Sistem Hukum Nasional, Gema Insani Press, Jakarta, 1996, hlm.66.

${ }^{25}$ Lihat, hlm. 22-23, Hazairin, Hukum Kewarisan Bilateral Menurut Qur'an dan Hadith. 


\section{Kalalah}

Arti kalalab telah dijelaskan oleh Allah sendiri dalam surah al Nisa ayat 176, yaitu "Jika seseorang mati dengan tidak ada baginya walad". Pengertian ini baru jelas jika telah diketahui apa maksudnya walad. Dalam al Nisa ayat 11 dijumpai bentuk jama' dari walad ini, yaitu awlad, dan di sama tegas dinyatakan bahwa awlad itu mungkin anak laki-laki, mungkin anak perempuan, mungkin bergandengan keduanya, dan mungkin pula tidak, seperti dalam kalimat "fa in kunna nisaa an". Maka jelaslah bahwa arti walad setiap macam anak, boleh anak laki-laki, boleh anak perempuan.

Oleh karenanya, berdasarkan pada pengertian yang terdapat dalam surah al Nisa ayat 12 dan 176, arti kalalah ialah keadaan seseorang yang meninggal dunia tanpa meninggalkan keturunan (mati punah), baik anak laki-laki atau perempuan. Rumusan baru yang digagasnya dalam konteks ini adalah, dengan memperluas pengertian anak menjadi keturunan. Pengertian seperti ini beliau kemukakan setelah menggabungkan pengertian yang terdapat pada ayat di atas dengan pengertian yang terdapat dalam ayat 33 surah yang sama.

Dengan demikian rumusan lengkap tentang maksud kalalab ini adalah keadaan seseorang yang mati punah, artinya mati dengan tidak berketurunan. Dalam sisten kewarisan bilateralyang digagasnya, maka keturunan dimaksudkan dengan setiap orang dalam garis lurus ke bawah, baik melalui pancar laki-laki maupun perempuan. Ia menyatakan bahwa Allah mengatur masalah (kalalah) ini dalam konteks pewaris masih memiliki kerabat menyamping, yakni semua macam hubungan persaudaraan, terlepas dari diskriminasi apapun juga. ${ }^{26}$

Mengenai arti akbun, ukbtun dan ikhwatun seperti ditemui dalam ayat-ayat kalalabitu, mestilah diingat bahwa kata-kata itu dipergunakan dalam al Qur'an dengan tidak memberikan sesuatu perincian tentang hubungan persaudaraan itu. Selaras dengan sistem kekeluargaan bilateral menurut Qur'an, maka yang dimaksud akhun, ukhtun dan ikhwatun adalah saudara dalam semua macam hubungan persaudaraan, baik karena pertalian darah dengan ayah ataupun ibu. Semua macam hubungan persaudaraan itu wajib ikut diperhitungkan dengan tidak mengartikannya secara berbeda-beda, seperti

\footnotetext{
${ }^{26}$ Lebih lanjut mengenai hal ini, lihat Hazairin, Kewarisan Bilateral, hlm. 50-56.
}

dalam surah al Nisa ayat 12 dan 176. Berlainan cara pembagian dalam kedua ayat kalalab itu tidak boleh menyebabkan berlainan pula tafsir mengenai hubungan persaudaraan itu.

Dalam hubungan ayah dan ibu, (seperti dalam al Nisa ayat 11), ayah dan ibu itu adalah ayah kandung dan ibu kandung, bagian ayah atau ibu itu dapat berbeda-beda menurut keadaan. Demikian juga dalam hubungan anak dengan anak, seperti dalam al Nisa ayat 11, anak-anak itu mungkin mendapat pembagian yang berbeda-beda menurut keadaan, sedangkan anak-anak itu jelas anak kandung bagi si mati. Karena itu maka kesamaan arti secara bilateral bagi akbun atau ukbtun dalam kedua ayat kalalab itu tidak perlu pula bermakna kesamaan bagi dasar pembagian.

Jika dibedakan dasar pembagian itu, seperti halnya dalam ayat-ayat kalalah tersebut, maka yang demikian tidak perlu menunjuk kepada sesuatu perbedaan mengenai hubungan persaudaraan dalam ayat 12 dan 176 itu. Karena Qur'an tidak memberikan perincian tentang macamnya perhubungan akbun dan ukbtun itu, sehingga semua macam perhubungan yang mungkin pada ayat 12 harus mungkin pula pada ayat 176 . Perbedaan dasar pembagian antara dua ayat itu bukanlah harus dicari sebabnya karena perbedaan macam perhubungan akbun dan ukbtun itu sendiri, namun yang harus dicari sebabnya itu adalah karena "keadaan lainnya".

Sambil menunjuk pada pelbagai sistem hubungan persaudaraan dalam hukum adat, Hazairin kemudian menyatakan bahwa dalam sistem kekeuargaan yang bilateral, maka saudara kandung itu mungkin artinya saudara sebapa atau mungkin pula saudara seibu, atau saudara sebapa dan seibu, sehingga termasuk di dalamnya semua jenis hubungan persaudaraan. Dalam sistem ini orang hanya mungkin bersaudara atau tidak bersaudara. Pengertian saudara tiri memang ada dalam masyarakat bilateral, namun yang disebut saudara tiri itu sama sekali bukan saudara, melainkan orang lain yang benar-benar tidak ada sangkut paut kedarahan apa-apa dengan orang yang menyebutnya, contohnya hubungan antara a dan $b$ di satu pihak dengan e dan $f$ di lain pihak sebagaimana yang dicontohkan dalam tulisannya.

Sebagai simpulannya terhadap ayat-ayat kalalah dimaksud, Hazairin mengungkapkan bahwa pada ayat 176 itu, Allah mengatur kewarisan seseorang yang mati tidak berketurunan, tapi ada meninggalkan saudara, yakni dalam hal ayahnya 
telah mati terlebih dahulu, (jadi mungkin ayah dan ibu sudah mati lebih dahulu atau mungkin ayah sudah mati tapi ibu masih hidup). Pada al Nisa ayat 12, Allah mengatur kewarisan sesoerang yang mati tidak berketurunan tapi ada meninggalkan saudara beserta ayah (jadi mungkin ibu juga masih hidup, atau mungkin ibu sudah mati).

Selain tiga persoalan pokok yang menjadi ide sentral pemikiran Hazairin, khususnya yang berkaitan dengan masalah kewarisan, (termasuk bidang perkawinan yang menjadi kewenangan Peradilan Agama), yang telah sedemikian julas dan mendapat perhatian yang demikian luas, namun tidak demikian halnya dalam bidang zakat, baitul mal, dan tentang emansipasi wanita. Persoalanpersoalan ini tampaknya hanya menjadi bagian (merupakan) kelengkapan dari rangkaian ijtihadnya dalam upaya mewujudkan cita-cita pembentukan madzhab ala Indonesia.

Dalam hal zakat misalnya, ia berpendapat bahwa, umat Islam Indonesia memerlukan undangundang atau peraturan pemerintah mengenai zakat yang harus disesuaikan dengan keadaan abad ke 20 ini. Sebab menurutnya, sistem zakat yang terdapat dalam fiqih madzhab tidak melengkapi lagi bagi kebutuhan hidup modern, sehingga diperlukan adanya perubahan dalam bentuk-bentuk dan caracara pelaksanaannya.

Jika demikian keadaannya, maka dari bank zakat itu bisa dikeluarkan pinjaman-pinjaman yang tidak berbunga (selain biaya administrasi) dengan jangka waktu yang relatif panjang. Ini dimaksudkan agar angsuran pembayarannya jadi ringan sehingga bisa menolong masyarakat miskin, dalam menciptakan hidup barunya yang produktif. Dengan itu katanya, kita akan memiliki satu bangunan yang dapat menandingi rumah-rumah gadai seperti sekarang ini, dan mampu bersanding dengan banka-bank besar yang sulit didekati oleh orang-orang yang betul-betul miskin. Fungsi zakat seperti ini baru bisa diwujudkan jika diadakan perubahan-perubahan dalam sistemnya, dan dengan sistem yang telah diperbaharui ini zakat dapat menjadi tulang punggung untuk mewujudkan kemakmuran rakyat, bukan hanya bagi umat Islam, tapi juga untuk non muslim (masyarakat) lainya. ${ }^{27}$

Dalam rangka mewujudkan madzhab Indonesia, Hazairin tak lupa pula menyingkap

${ }^{27}$ Hazairin, Tujuh Serangkai Tentang Hukum, op cit, hlm. 143-144. pemikirannya di bidang pidana Islam. Ini termasuk pemikiran yang sangat langka, karena beliaulah satusatunya pemikir muslim Indonesia yang secara mengagumkan menawarkan sebuah konsep "Negara Tanpa penjara" yang menurut ukuran umum sangatlah mustahil, dan hanya angan-angan kosong semata. Dengan konsep ini, Hazairin ingin menggambarkan bagaimana Qur'an dan Rasulullah saw. mengatur negara tanpa memerlukan penjara, dengan menjalankan sistem pidana Islam. Ajaran Islam (Qur'an dan hadits) ternyata tidak pernah menetapkan wajib adanya hukuman penjara atau menyediakannya, bahkan tidak menganjurkan atau mengajarkannya. ${ }^{28}$

Sehubungan dengan gagasannya ini, ia mengutarakan perlu diadakan undang-undang yang menampung masuknya hukum pidana Islam, yang menjamin diberlakukannya bagi masyarakat muslim Indonesia. Karean hukum pidana Islam itu sedikit, menurutnya hukum tersebut dijadikan saja sebagai hukum pidana khusus, di samping pidana umum yang terhimpun dalam KUHP. Peradilan yang berwenang untuk memeriksa perkara-perkara pidana Islam itu adalah peradilan umum. Di dalam sidang-sidangnya harus diketuai oleh seorang hakim yang muslim dan ahli dalam bidang hukum pidana Islam.

Demikian, beberapa butir pemikiran sang tokoh, baik yang berkaitan dengan upaya pembaharuan hukum Islam, maupun dalam berbagai bidang materi hukum yang menjadi ciri dari madz̧ab Indonesia yang dicita-citakannya.

\section{Analisis}

Hazairin, adalah tokoh dan pemikir muslim kenamaan yang keseluruhan gagasannya disuarakan demi dan untuk kepentingan bangsa Indonesia modern yang terbebas dari kungkungan pemikiran klasik, yang menurutnya perlu diadakan upayaupaya terobosan baru (pembaharuan) sesuai dengan kenyataan sosio-kultural yang tengah dihadapi bangsa ini.

Sebenarnya, ia termasuk salah seorang politisi, namun namanya lebih populer dalam dunia ilmiah terkait dengan sosoknya yng dikenal sebagai orang yang senantiasa menekuni pendidikannya di lembaga-lembaga pendidikan. Islam yang dipelajarinya secara autodidak, justru menghantar-

${ }^{28}$ Ibid. 
kannya pada pakar hukum Islam Indonesia sekaligus ahli dalam bidang hukum adat.

Sebagai seorang pembaharu hukum Islam, yang sebelumnya telah memfokuskan perhatian pada hukum adat, (digeluti hampir seperempat abad lamanya) kemudian sampailah ia pada suatu simpulan bahwa "masyarakat adat yang berbagai jenis sistem kekeluargaan, sesuai dengan cara mereka menarik garis keturunan, semuanya telah dipengaruhi oleh faktor luar dan dalam yang bertujuan untuk menyalurkan masyarakat ber clanclan seperti patrilineal, matrilineal, parental atau bahkan patrilineal beralih-alih (patrilineal alternating system) itu, ke arah yang bilateral".

Atas dasar keyakinan, menurutnya, faktorfaktor tersebut semuanya merupakan tenaga-tenaga pembantu dalam alam ini untuk mencapai tujuan Qur'an menjelmakan masyarakat yang bilateral bagi seluruh umat. Hasil ijtihad yang beliau hubungkan dengan hukum perkawinan dan kewarisan yang menentukan dan mnecerminkan sistem kekeluargaan yang berlaku dalam suatu masyarakat, memberikan kesan bahwa Islam sebenarnya hendak menghancurkan sistem kemasyarakatan yang dipraktikkan oleh masyarakat adat.

Terkait dengan itu, sistem kemasyarakatan bilateral yang diyakininya, sebagai tafsirannya terhadap ayat-ayat al Qur'an yang anti dan tidak menyukai masyarakat unilateral, menggugahnya untuk menyuarakan sekaligus menjadi bahan telaah penting dan pertimbangan sebagai masukan berharga bagi kepentingan perundang-undangan di masa sesudahnya, seperti masalah waris pengganti (mawali) termasuk kalalah.

Bagi hazairin, penggantian waris oleh cucu yang orang tuanya meninggal elbhi dahulu dari pewaris, mutlak diberlakukan jika memamng tidak ada lagi penghubungnya yang masih hidup, meskipun cucu tersebut mewaris bersama anak lakilaki lain dari pewaris. Penyelesaian seperti ini tidak diberlakukan oleh sistem kewarisan yang patrilineal, karena anak laki-laki menempati posisi atau "derajat" di atas daripada cucu, meskipun keduanya berada dalam satu jibat, yaitu jihat bunumwah. ${ }^{29}$ Sistem penggantian yang dipahaminya juga berlaku dalam garis lurus ke atas dan menyamping, sehingga

\footnotetext{
29 Tetapi dilihat dari aspek "derajat" anak (laki-laki) menghijab cucu pewaris, karena derajatnya lebih dekat dan didahulukan dalam penentuan giliran "ashobah bi al nafsi" untuk mengambil bagiannya (sisa).
}

ijtihadnya ini barangkali dipandang lebih maju dari aspirasi masyarakat muslim selama ini terkait dengan masalah kasus kewarisan "patah titi".

Terhadap masalah kalalah atau mati punah, ia menyimpulkan bahwa seseorang yang meninggal dunia tanpa keturunan itu, tidak terbatas pada furu' si mati yang laki-laki saja. Ini mempunyai konsekuensi atau akibat hukum bahwa anak perempuan pun bisa menghabiskan seluruh harta peninggalan pewarisnya meskipun di sampingnya masih terdapat ahli waris nasabiyah yang hawasyi seperti saudara pewaris. Dengan kata lain, saudara (laki-laki atau perempuan) terbijab hirman dengan adanya anak dalam struktur kewarisan itu, sekalipun hanya anak perempuan.

Sebagai contoh, ketika struktur waris terdiri dari seorang isteri, satu orang anak perempuan, satu orang saudara laki-laki, dan satu orang anak dari saudara laki-laki, maka penyelesaian kasusnya menurut Hazairin adalah, isteri berhak 1/8, anak perempuan $1 / 2+3 / 8$ (raddnya), sedangkan saudara laki-laki dan anaknya terhijba oleh anak perempuan, sebab anak (termasuk perempuan) menempati kelompok keutamaan pertama. Sesuai dengan makna walad di surah al Nisa ayat 11 yang dipahaminya, bahwa "walad" tersebut tidak dimaksudkan terbatas pada anak laki-laki saja. ${ }^{30}$

Hazairin $^{31}$, cenderung menginginkan konstitusionalisasi hukum Islam melalui kodifikasi dan unifikasi. Ia mengacu kepada semangat Piagam Jakarta, dengan melakukan interpretasi baru terhadap teks-teks ayat al Qur'an dan al Sunnah. Ini dapat dilihat misalnya dalam karyanya "Kewarisan Bilateral menurut Qur'an dan Hadith" yang memberikan gambaran mengenai semangat dan pendekatan yang dilakukannya. ${ }^{32}$

Gagasan-gagasan yang dikembangkannya, pada awalnya memang kurang mendapat respon dan apresiasi yang memadai, atau bahkan sempat menjadi polemik, namun setelah melalui perjuangan yang gigih dan panjang serta ditindaklanjuti oleh para sarjana dan ulama sesudahnya, akhirnya

${ }^{30}$ Di lembaga peradilan, khususnya Pengadilan Agama, (sekarang) terdapat putusan/penetapan hukum terkait kasus anak perempuan yang menghijab saudara pewaris ini. Seperti kasus Nomor

31 Pemikiran tentang perlunya pembaharuan hukum Islam ini dilakukannya secara konsisten dan konsern yang tinggi.

32 Ahmad Rofiq, Fiqh Kontekstual dari Normatif ke Pemaknaan Sosial, Pustaka Pelajar, 2004, cet. I, hlm. 21. 
membuahkan hasil bagi pelaksanaan "hukum Islam" di Indonesia.

Lahirnya Undang-Undang Nomor 7 tahun 1989, Undang-Undang Perkawinan Nomor 1 tahun 1974, dan Kompilasi hukum Islam tahun 1991, serta seperangkat aturan dan perundangan lainnya, seperti Undang-Undang Zakat dan terakhir tentang Perubahan atas Undang-Undang Nomor 7 tahun $1989^{33}$, secara keseluruhan merupakan realisasi dari ide-ide pemikirannya terkait dengan gagasangagasannya yang menginginkan adanya keseragaman Peradilan Agama, yang tidak lagi memerlukan (adanya) executoir verklaring dari pengadilan umum, termasuk Pengadilan Agama yang langsung berada di bawah pengawasan Badan Mahkamah Agung, dan hal-hal lain sebagaimana disebutkan dalam uraian terdahulu tentang ide-ide pemikirannya.

Salah satu karakteristik hukum Islam di Indonesia adalah bahwa ia tidak sama dan sebangun dengan syariah. Ungkapan al Syara i mutahaddidah wa al waqa $i$ ' mutajaddidah, menunjukkan bahwa hukum Islam diharapkan dapat merspon modernisasi dengan segala dampaknya, maka reinterpretasi dan reformulasi hukum Islam mutlak tidak bisa dihindarkan (conditio sinequanon), ${ }^{34}$ Hazairin tergolong salah seorang tokoh yang melihat kenyataan ini, untuk selanjutnya berupaya melakukan terobosan-terobosan baru terkait dengan kondisi masyarakat dan dihubungkan dengan tafsirannya terhadap ayat-ayat al Qur'an atau hadits-hadits hukum, utamanya dalam lingkup perkawinan dan kewarisan.

Pemikiran hukum Hazairin yang terpenting dalam konteks kewarisan adalah masalah mawali atau waris pengganti yang sepeninggalnya, diwujudkan melalui Kompilasi Hukum Islam buku II bab III tentang Besarnya Bagian, pasal 185 ayat (1 dan 2). Pemunculan pasal ini tela menjawab apa yang selama ini dituduhkan dan dirasakan sebagai suatu ketidakadilan dari hukum waris Islam yang bersumber dari pemahaman fuqaha dalam kitabkitab fiqih klasiknya. ${ }^{35}$

\footnotetext{
33 Yaitu Undang-Undang Nomor 3 Tahun 2006 dan Undang-Undang Nomor 50 Tahun 2009.

${ }^{34}$ Ibid.

35 Sebab mereka mendasarkan pada hadits manqufZaid bin Tsabit tentang terhalangnya seorang cucu, baik laki-laki, apalagi perempuan dalam struktur kasus waris yang di dalamnya ada anak laki-laki lain (paman dari cucu-cucu yang orang tuanya meninggal lebih dahulu dari si
}

Hilangnya hak opsi dan volunter waris pasca lahirnya Undang-Undang Nomor 3 tahun 2006 menjadikan pasal kewarisan mawali versi KHI di atas, termasuk persoalan anak angkat, ${ }^{36}$ semakin kukuh dan menjamin rasa keadilan bagi segenap pemakai hukum waris Islam, dan ini tentunya tidak luput dari sumbang saran sang penggagasnya.

Dengan tetap konsekuen berpegang pada sumber asli al Qur'an dan hadits, ia berijtihad dengan mempertimbangkan kondisi sosial kemasyarakatan yang telah dipengaruhi beragam kemajuan. Sehingga "apa yang cocok untuk suatu masa, belum tentu akan sesuai dengan berubahnya zaman" senantiasa menjadi bahan pertimbangan baginya dalam merumuskan suatu kesimpulan hukum, sepanjang tidak berbenturan dengan syariat.

Pemahaman mendalam terhadap nash sambil menghubungkannya dengan kenyataan, "ijtihad" mutlak diperlukan, meski tetap berorientasi pada pendapat atau madzhab yang sudah mapan. Oleh karenanya, ia telah menawarkan satu konsep tentang madz̧bab Indonesia sesuai dengan definisi operasional di atas. Oleh sebab itu, adanya fiqih Indonesia, Kompilasi Hukum Islam, dan terbentuknya Sistem Peradilan Agama di Indonesia secara historis tidak terlepas dari rangkaian sejarah, dan Hazairin merupakan salah seorang yang turut berperan di dalamnya.

Memperhatikan kenyataan ini, Hazairin dengan segala ide dan upaya pembaharuannya, dapat digarisbawahi bahwa, ia termasuk salah seorang tokoh pembaharu muslim Indonesia modern yang tergolong moderat sesuai dengsn kelompoknya. Karena di samping ia tetap konsisten berpegang pada sumber asli al Qur'an dan Hadits termasuk kitab-kitab fiqih klasik, ia juga peduli

pewaris). Karena anak laki-laki tersebut akan menghijab kewarisan cucu yang secara urut-urutan ashobah memang berada pada "derajat" di bawahnya, meskipun masih dalam satu "jihat".

36 Yang disebut-sebut sebagai salah satu sebab hukum waris Islam itu tidak adil. Oleh buku II Kompilasi Hukum Islam Bab V tentang Wasiat pada pasal 209 ayat 2 secara jelas dinyatakan bahwa anak angkat mendapat bagian maksimal sepertiga harta warisan orang tua angkatnya. Tidak hanya itu, pasal ini juga berlaku timbal balik terhadap orang tua angkat yang tidak diberi wasiat (ayat 1 pasal 209) secara ikhtiyariyah. Artinya, baik anak angkat ataupun orang tua angkat bisa mendapat bagian dari harta peninggalan pewaris dengan jalan wasiat wajibah 
terhadap kondisi sosial kemasyarakatan yang terus berubah seiring dengan kemajuan zaman. Sebagai sosok yang berpikiran moderat, dan dengan pendekatan yang normatif, ia berusaha memadukan dua pemikiran (salafy dan asbrany) serta mendahulukan sesuatu yang bersifat universal.

\section{Penutup}

Hazairin Gelar Pangeran Alamsyah adalah seorang pembela hukum Islam yang gigih. Meski hidup dan pendidikannya banyak dihabiskan dalam dunia pendidikan umum, namun Islam yang dipelajarinya secara auttodidak justru telah mengharumkan namanya dengan julukan sebagai tokoh pembaharu hukum Islam modern.

Pengetahuan dan kemahirannya di bidan hukum adat turut membantu upaya pembaharuan yang dilakukannya dalam konteks hukum keluarga seperti perkawinan dan kewarisan. Atas dasar itu pula, ia sampai pada ijtihadnya yang menyimpulkan bahwa sistem kemasyarakatan yang dikehendaki al Qur'an adalah sistem yang bukan berclan-clan atau anti unilateral.

Sesuai dengan sistem atau cara menarik garis keturunan ini, persoalan waris mewarisi dalam Islam pun menghendaki corak yang parental/ bilateral, jika dihubungkan dengan beberapa ayat kewarisan seperti ayat 11, 12, dan 176 surah al Nisa. Terkait dengan masalah ini, interpretasinya terhadap surah yang sama ayat 33 menghasilkan sebuah pemikiran yang cukup simpatik, dan pada gilirannya istilah mawali atau populer dengan istilah "waris pengganti" ini, diadopsi oleh Kompilasi Hukum Islam (KHI) buku II, bab III pasal 185 ayat (1 dan 2).

Perangkat hukum yang dilahirkan melalui Instruski Presiden RI. Nomor 1 tahun 1991 ini, kemudian atas dasar keputusan Menteri Agama RI. Nomor 154 tahun 1991 tentang pelaksanaan Inpres dimaksud, sampai sekarang tetap akan menjadi pedoman dan acuan bagi setiap Pengadilan Agama dalam menyelesaikan masalah-masalah kewarisannya. Itu artinya tidak ada alasan untuk menyatakan hukum waris Islam "tidak adil".

Kesungguhan berpikir yang telah dihasilkan Hazairin, di satu sisi terkadang dianggap sebagai pendapat yang kontroversial, namun di sisi lain terobosan barunya ini justru telah diirealisasikan melalui sejumlah aturan perundang-undangan. Sehingga terbukti apa yang telah dicatat oleh Alyasa
Abu Bakar $^{37}$ bahwa pada saatnya, usaha pembaharuan yang telah dilakukannya akan sangat mempengaruhi perkembangan fiqih di Indonesia.

Upayanya untuk merekonstruksi fiqih Indonesia, dengan meninggalkan penyelesaian cara-cara lama terhadap persoalan-persoalan yang muncul dan dihadapi ulama sekarang ini misalnya, secara parsial dan merujuk kepada latar belakang adat masyarakat Arab, sudah tidak memadai, bahkan mungkin tidak dapat menyelesaikan persoalan. Atas dasar itu pula, Hazairin mengajukan alternatif, yaitu suatu pemahaman yang sistematis, padu dan menyeluruh terhadap dalil nash seraya memanfaatkan hasil kajian ilmu kontemporer, dengan tujuan akhirnya menciptakan sebuah sistem yang lebih universal, bahkan final.

Keinginannya untuk memperbaik "wajah hukum" yang ada di tengah masyarakat muslim Indonesia, agar semaksimal mungkin disesuaikan dengan tuntuan Qur'an (Islami). Atau dengan kata lain, agar masyarakat muslim itu dapat melaksanakan keinginan-keinginan Qur'an tanpa perlu membuang budaya dan nilai yang tidak bertentangan dengan sumber asli. Dari titik pandang ini, kelahiran madzhab fiqih Indonesia adalah sesuatu yang wajar dan merupakan bagian dari proses sejarah, dan upayanya ini patut dihargai sekaligus dipertimbangkan dengan segenap perhatian. ${ }^{38}$

Berbagai pemikiran yang dilontarkan Hazairin, seputar pemikirannya dalam kerangka mewujudkan cita-citanya membentuk suatu madz̧hab Indonesia, sebagian besar tampaknya sudah terealisasi lewat kehadiran beberapa aturan dan perundangundangan yang ada seperti, Undang-Undang Nomor 1 tahun 1974, Undang-Undang Nomor 7 tahun 1989, Kompilasi Hukum Islam tahun 1991, Undang-Undang Zakat, dan kemudian Undang-

${ }^{37}$ Al Yasa Abu Bakar, Abli Waris Sepertalian Darab; Kajian Perbandingan Terbadap Penalaran Hazairin dan Penalaran Fiqib Madžhab, INIS, Jakarta, cet. I, 1988, hal. 214-215.

${ }^{38}$ Dari berbagai pemikiran yang diperkenalkan Hazairin kepada bangsa Indonesia, maka sepantasnyalah bila sosok Hazairin menjadi sosok yang cukup penting dalam jajaran kaum pembaharu. Sehubungan dengan itu, Bismar Siregar, mantan Hakim Agung RI. menjulukinya sebagai seorang mujahid penegak hukum. Kiranya semua warisan yang ditinggalkannya itu akan menjadi "barang berharga" yang membawa manfaat, dan kerja kerasnya menjadi contoh teladan bagi generasi sesudahnya. (Seperti dikutip dari Mimbar Hukum, hal. 79). 
Undang Nomor 3 tahun 2006, Undang-Undang Nomor 50 tahun 2009, menyangkut perubahan atas Undang-Undang Peradilan Agama.

\section{Daftar Pustaka}

A. Qodri Azizy, Eklektisisme Hukum Nasional Kompetisi antara Hukum Islam dan Hukum Umum, Gama Media, Yogyakarta, Pebruari 2002, cet. Pertama.

Ahmad Rofiq, Fiqh Kontelestual dari Normatif ke Pemaknaan Sosial, Pustaka Pelajar, 2004, cet. I, hal. 21.

Amrullah Ahmad, Dimensi Hukum Islam dalam Sistem Hukum Nasional, Gema Insani Press, Jakarta, 1996, hal.66.

Al Yasa Abu Bakar, Abli Waris Sepertalian Darab; Kajian Perbandingan Terbadap Penalaran Hazairin dan Penalaran Fiqib Madzhab, INIS, Jakarta, cet. I, 1988.
Daniel S. Lev, Peradilan Agama Islam di Indonesia: Suatu Studi tentang Landasan Politik LembagaLembaga Hukum, terj. Z.A. Noeh dari Islamic Courts in Indonesia, PT. Intermasa, Jakarta, 1980, cet. I,

Hazairin, Tujuh Serangkai tentang Hukum, Bina Aksara, 1981, cet. II.

Hazairin, Hukum Kewarisan Bilateral Menurut Qur'an dan Hadits, Tintamas, Jakarta, 1982, cet. VI, hal.12.

Hazairin, Hukum Kewarisan Bilateral Menurut Qur'an dan Hadith.

Mimbar Hukum, No. 44 Tahun X, 1999, September-Oktober, PT. Tomasu, hal. 65.

Tim Redaksi Majalah Tempo, Apa dan Siapa Sejumlah Orang Indonesia 1981-1982), Grafiti Pers, Jakarta, 1981, hal. 219. 